() О. В. Тріщук, д-р наук із соц. комунікацій, проф., Н. М. Фіголь, канд. філол. наук, доц., Н. С. Волик, студентка, КПІ ім. Ігоря Сікорського, Київ, Україна

\title{
ГЕЙМІФІКАЦІЯ В ОСВІТНЬОМУ ПРОЦЕСІ
}

\section{У статті структуровано етапи становлення гейміфікації як соціального та культурного явища, і як наукового терміна, запропоновано критерії однозначності засобів гейміфікації, розроблено метод аналізу ефективності гейміфікованих матеріалів.}

\section{Ключові слова: гейміфікація; гейміфікований контент; мотивація; ігри; тести; користувач.}

\section{Постановка проблеми}

У наш час споживацької розважальної психології, спрямованої на отримання швидкого задоволення, інтерес до гейміфікації зростає з кожним роком. Ігрові компоненти проникають у всі сфери діяльності, особливо помітне місце вони починають займати в навчанні та виробничій сфері: нікого вже не здивувати тренінгами й квестами, спрямованими на засвоєння певних навичок. Освітня система активно переходить від академічної лекційної моделі до тренінгової. Однак, новітні реформи часто лише супроводжуються лише новою термінологією, навіть не завжди усвідомленою навіть реформаторами: існує багато публікацій про використання ігрових компонентів під час оволодіння англійською мовою, водночас стосовно інших предметів новітній підхід застосовують рідко, він тримається тільки на ентузіазмі окремих творчих викладачів. Усвідомлюючи важливість переходу освітньої системи до нових форм, ми звернулись до новітнього методу - гейміфікації, яка має великий потенціал використання в усіх сферах людської діяльності, зокрема в освітній, що й зумовлює актуальність нашої роботи.

\section{Мета роботи}

Визначення соціально-комунікаційної сутності гейміфікації та особливостей її функціонування в освітньому процесі.

\section{Аналіз попередніх \\ досліджень}

Поняття та процеси гейміфікації на сьогодні активно досліджують як зарубіжні, так і українські науковці. Слід виділити напрямки вивчення таких іноземних дослідників: Н. Пелінг [1] (одним з перших застосував термін «гейміфікація»); Г. Зікерманн [2] (уперше дослідив використання елементів гри в неігровому середовищі); Р. Бартл [3] (запропонував класифікацію гравців, на яку варто зважати для ефективного запро-

() $2019 \mathrm{p}$. 
вадження гейміфікації); Е. Кім [4], К. Капп [5] (досліджували поняттєвий апарат та основні особливості гейміфікації); К. Вербах та Д. Хантер [6] (виділяють внутрішню та зовнішню гейміфікацію); К. Хуотарі та Дж. Хамарі [7] (порівнюють психологічні ефекти впливу з механікою ігор); Д. Кларк [8] (дослідив вплив ефекту ігор на мотивацію в навчанні); Ф. Грох [9] (визначив гейміфікацію прийнятним методом для застосування дизайну ігор у неігровому контексті).

Серед вітчизняних досліджень варто виділити праці А. Мостової [10], яка досліджувала поняття гейміфікації та її роль у маркетингу; А. Безчотнікової [11], яка вивчала застосування гейміфікації для вирішення рекламних та PR-завдань; Г. Середи [12], дослідившого гейміфікацію в менеджменті персоналу; Н. Головко [13] розглядала ігрові технології як засіб активізації пізнавальної діяльності студентів; Л. Сергеєва [14] висвітлює змагальний аспект гейміфікації, який $€$ запорукою конкуренції, покладеної в основу бізнесу.

Окрім наукових статей щодо гейміфікації, можна виділити і вебінари з цієї проблематики: застосування гейміфікації у щоденному житті пропагує $€$. Алефіренко [15]; С. Насирова у вебінарі «Гейміфікація як інструмент розвитку бізнесу» пропонує використовувати ігрові елементи в бізнесі [16].

\section{Результати проведених досліджень}

Під час проведення досліджень використовувались такі методи: аналіз - проведено аналіз літе- ратурних джерел з теми гейміфікації в Україні та світі; контентаналіз - зафіксовано та проаналізовано конкретні приклади впровадження гейміфікації, встановлено критерії її ефективності.

Для вивчення явища гейміфікації необхідно, перш за все, визначитися 3 термінологічним апаратом. Опрацювання цього теоретичного матеріалу дасть змогу сформувати цілісне уявлення про явище гейміфікації, а також виділити в дослідженнях аспекти, які були недостатньо розкриті або потребують уточнення.

Існує декілька способів утворення нового терміна: запозичення; словотворчі кальки; власні утворення. Багато слів-термінів утворилось від латинських, грецьких, німецьких основ, часто через посередництво російської мови, завдяки пристосуванню до власне українських словотвірних моделей.

Термін «гейміфікація» створено одним з найпростіших способів утворення терміна на запозиченій основі - транскодуванням побуквеній чи пофонемній передачі вихідної лексичної одиниці за допомогою алфавіту мови перекладу. Зокрема, у нашому випадку йдеться про змішане транскодування, коли частково зберігається оригінальне звучання та графічна форма терміна (корінь), однак вони поєднуються із характерними одиницями мовиреципієнта (афікси) [17].

Такий спосіб термінотворення використовують для позначення нових термінів, які не мають відповідників у власній мові. Він особливо ефективний, коли слово має лише одне значення і буде інформативним, чітко застосовуватись 
за призначенням, називаючи певне поняття. Важливо також, щоб це слово ефективно та природно вступало в термінологічні стосунки, утворюючи продуктивні гнізда термінів, тобто було продуктивним деривативом, що й відбувається з нашим терміном: «гейміфікувати», «гейміфікація», «гейміфікування», «гейміфікований».

Ще одним поширеним терміном на позначення досліджуваного нами явища $€$ «ігрофікація», який утворений дещо іншим способом (за допомогою калькування) і означає англійське «gamification». Згідно з Н. Абабіловою, цей принцип заснований на передачі «комбінаторного складу слова, коли складові частини слова (морфеми) чи фрази (лексеми) перекладаються відповідними елементами мови перекладу. Це переклад англійського слова або виразу шляхом точної передачі його засобами української мови» [17]. Цей прийом зазвичай використовують для перекладу складних за структурою термінів.

Отже, всі зазначені терміни функціонують в українському науковому просторі і $€$ різними назвами одного поняття, проте дедалі більше спостерігається тенденція - до використання єдиного варіанта - «гейміфікація», що свідчить про етап унормування термінологічного апарату і сприятиме уникненню небажаної плутанини надалі.

Таким чином, можна стверджувати, що гейміфікація або ігрофікація - це використання окремих ігрових елементів у неігрових ситуаціях. При цьому ігрові елементи залучаються до реальних об- ставин для мотивування учасників процесу на певні дії або поведінкові реакції.

Від решти ігрових форм гейміфікацію відрізняє направленість учасників процесу на реальну мету, пов'язану з власною діяльністю, а не на гру заради гри, тому саме в силі мотивації полягає успішність цього методу.

Науковці виділяють три основні напрями впливу гейміфікації: 1) реалізація мотиваційних рішень; 2) психологія приймання рішень; 3) подальші поведінкові результати.

Сьогодні явище гейміфікації активно застосовується у багатьох сферах людської діяльності, водночас нерозривно воно пов'язане зі сферою навчання, де якнайкраще демонструє свою ефективність. В англомовних джерелах дослідники, аби позначити одну зі сфер ефективного впливу гейміфікації, часто звертаються до терміна «мікронавчання».

У 2004 році Г. Гаслер уперше ввів термін «мікронавчання», розуміючи його як спосіб, в якому поняття та ідеї подано фрагментарно, так як передбачено короткі інтервали, що створюють ефективні умови для максимального сприйняття інформації [18]. Мікронавчання $€$ ідеальною базою для гейміфікації, оскільки студенти за допомогою ігор можуть опановувати матеріал, вдосконалювати свої навички та перевіряти правильність певних теорій та ефективність засвоєння матеріалу.

У 2003 році Ч. Вебер запропонував теорію «швидкого навчання у швидкозмінному середовищі», яка полягала у поєднанні вивчення порівняно невеликого 
обсягу навчального матеріалу (що легко розташовується на екрані) та короткострокового навчання [19].

Дослідник Т. Хаг вважає, що метод мікронавчання особливо прийнятний в закладах вищої освіти та для підвищення кваліфікації, оскільки сприяє покращенню знань та швидкому закріпленню необхідних навичок [20]. У цьому процесі велику роль відіграє мотивація. Оскільки здобувачі вищої освіти та професіонали-початківці свідомі та мотивовані, вони націлені на швидкий результат і розуміють, навіщо їм це потрібно. При цьому ефективно працює метод коротких виступів та обговорення в групі, що найкраще формує практичні навички.

Науковець Р. Оросова у статті щодо застосування мікронавчання називає такі етапи досліджуваного процесу:

- проведення мікронавчання. Етап триває 10-15 хвилин. Впродовж цього часу студент має викласти сутність визначеного завдання або пояснити важливі для подальшого обговорення аспекти матеріалу. Інші студенти оцінюють його діяльність згідно з попередньо визначеними критеріями;

- аналіз мікронавчання. Цей етап базується на обговоренні та оцінюванні виступу студента всією групою, тобто триває безпосереднє залучення інших у тему;

- повторне мікронавчання. Останній етап, на якому студент знову, але з урахуванням рекомендацій, повторює свої дії і демонструє на практиці сформовані вміння [21].
Специфікою мікронавчання $\epsilon$ те, що воно не обмежується часовими та просторовими рамками, одним із його проявів є мобільне навчання, яке дає змогу навчатися у будь-який вільний час, на відміну від електронного або традиційного навчання.

На сьогодні найпрогресивнішою сферою людської діяльності, в якій найбільше запроваджують гейміфіковані елементи, є освіта.

У 2013 році у Гарвардському університеті Ерік де Брош де Комб увів курс «Immersive Landscape», у якому передбачалось вивчення ландшафту за допомогою ігрових технологій.

У Нью-Йорку департаментом освіти за підтримки Фонду Макартура та Фонду Білла та Мелінди Гейтс було створено школу під назвою «Quest to Learn», де провадиться навчання за допомогою гри.

Проте елементи гейміфікації не потрібно розуміти спрощено і думати, що ця методика обмежується вивченням букв та чисел за допомогою різних героїв. На сьогодні дедалі активніше впроваджуються нові елементи освітньої гейміфікації.

У 2018 році у польській школі міста Глівіце вдало імплементовано ігрові елементи у вивчення літератури. У цьому проекті учні мали самі створити гру за сюжетом літературного твору. Таким чином, діти, створюючи власну гру, оволодівали новим матеріалом, занурювались у цікавий світ класичної літератури.

Подібна ідея використання гейміфікованих елементів спала на думку і була реалізована вчителем географії Девідом Гантером, який вирішив змінити класичний 
виклад матеріалу. Дітям було запропоновано захопливу гру з цікавим для сучасних підлітків сюжетом (події відбувалися у світі зомбі), під час якої вони були змушені вивчати питання географії щодо міграції, особливостей рельєфу та клімату для проходження певних завдань.

В Україні одним із перших гейміфікованих проектів $є$ середовище UNIT Factory, розраховане на 900 студентів, націлених здобувати знання з програмування. У проекті використано запозичений у французької школи «42» метод, який полягає в тому, що студенти вчаться один в одного із залученням елементів гейміфікації.

Таким чином, використання гейміфікованих елементів дозволяє у процесі гри отримувати корисний досвід та знання, сприяє тому, що студенти опрацьовують реальні кейси, ситуації і водночас отримують навички роботи в команді, використовуючи основи критичного мислення.

\section{Висновки}

На сьогодні гейміфікація має значний вплив на життя кожної людини, хоча ми можемо цього не помічати та не усвідомлювати.
3 екрану смартфона, ноутбука, комп'ютера щохвилини на нас ллється величезний потік інформації, яка досить часто модифікована під гру або сприймається як така, проте це не заважає нам використовувати ігрові елементи як стимул та потенціал до саморозвитку. Ринок гейміфікованих технологій активно розвивається, як в Україні, так і у всьому світі, бо таким чином залучається нова аудиторія. Водночас, ігрові технології активно впроваджують до освітнього процесу для підтримки зацікавленості та ефективності роботи студентів. Мотивування за допомогою гейміфікації стає найдієвішим способом взаємодії як великих корпорацій, так і кожного зокрема. Проте науковцям ще потрібно усвідомити та відрізнити корисний потенціал гри від гри як самоцілі, що може шкідливо позначитись як на психічному та фізичному здоров'ї, так і на самореалізації в соціумі, тому з гейміфікацією потрібно бути досить обережним. Вивчення застосування гейміфікації у різних сферах діяльності, межі корисного та шкідливого і можуть стати перспективою подальших досліджень.

\section{Список використаної літератури}

1. Pelling N. The Short Prehistory of Gamification. Funding Star tups (\& Other Impossibilities) / N. Pelling // Nano Dome: website. URL: https://nanodome.wordpress.com/2011/08/09/the-short-prehistory-of-gamification/.

2. Zichermann G. Game mechanics in web and mobile apps / G. Zichermann. California: O’Reilly Media, 2011. 182 p.

3. Bartle R. Designing virtual worlds / R. Bartle. New Riders, 2004. 741 p.

4. Kim A. Community building on the web: Secret strategies for successful online communitie / A. Kim. Addison-Wesley: Longman Publishing Co., 2010. $380 \mathrm{p}$.

5. Kap K. The gamification of learning and instruction: game-based methods and strategies for training and education / K. Kap. San Francisco: Pfeiffer, 2012. $336 \mathrm{p}$. 
6. Werbach K. Forthewin: how game thinking can revolutionize your business / K. Werbach, D. Hunter. Philadelphia: Wharton Digital Press, 2012. 148 p.

7. Huotari K. Defining gamification: a service marketing perspective / K. Huotari, J. Hamari // In Proceedings of the 16th International Academic Mind Trek Conference, October 3-5, 2012, Tampere, Finland: ACM, pp. 17-22.

8. Clark D. Games and e-learning / D. Clark. St. Peters Gate: Caspian Learning Ltd., 2006. $31 \mathrm{p}$.

9. Groh F. Gamification: State of the Art Definition and Utilization / F. Groh // Paper presented at the 4th Seminar on Research Trends in Media Informatics, UIm, 2012. pp. 39-46.

10. Мостова А. Д. Поняття гейміфікації та їі роль у маркетингу / А. Д. Мостова // Європейський вектор економічного розвитку. 2018. № 1(24). С. 96-106. DOI: 10.32342/2074-5362-2018-24-9.

11. Безчотнікова А. О. Застосування гейміфікації для вирішення рекламних та PR-завдань / A. О. Безчотнікова // Вісник Дніпропетровського університету. Серія «Соціальні комунікації», 2016. Вип. 16. С. 8-18.

12. Середа Г. В. Гейміфікація в менеджменті персоналу: зарубіжний та український досвід / Г. В. Середа // Економіка і організація управління. 2017. № 4 (28). С. 216-223.

13. Головко Н. І. Ігрові технології як засіб активізації пізнавальної діяльності студентів / Н. І. Головко // Вісник Київського національного університету імені Тараса Шевченка. Серія Педагогіка. 2015. № 1(1). С. 17-20.

14. Сергеєва Л. Гейміфікація: ігрові механіки мотивації персоналу / л. Сергеєва // Theory and methods of educational management: веб-сайт. URL: http://umo.edu.ua/images/content/nashi_vydanya/metod_upr_osvit/ v 15/14.pdf.

15. Що таке гейміфікаціяі чому вона корисна / Youtube: веб-сайт. URL: https://www.youtube.com/watch?v=vvVLYhVckR8.

16. Насирова С. Гейміфікація як ефективний інструмент мотивації персоналу сучасної організації / С. Насирова // Науковий огляд, 2019. № 3. C. 6-16.

17. Абабілова Н. М. Особливості перекладу термінів українською мовою / Н. М. Абабілова // Молодий вчений, 2015. № 2. С. 126-128.

18. Gassler G. Integrated Micro Learning - Anoutline of the basic method and first results / G. Gassler, T. Hug, C. Glahn // International Conference on Interactive Computer Aided Learning. Villach, Austria, 2004. pp. 1-7.

19. Weber Ch. Rapid learning in high velocity environment: dissertation to the degree of doctor of Philosophy In Management of Technological Innovation and Entrepreneurship / Ch. Weber. Massachusetts: Massachusetts Institute of Technology, 2003. 569 p.

20. Hug T. Micro Learning and Narration Exploring possibilities of utilization of narrations and storytelling for the designing of 'microunits' and didactical micro-learning arrangements / T. Hug. Cambridge. 2006. pp. 7-11.

21. Оросова Р. Застосування мікронавчання у процесі вивчення курсу «загальна дидактика» в Кошицькому університеті імені Павла Йозефа Шафарика / Р. Оросова // Наук. вісн. Ужгород. нац. ун-ту. Сер.: Педагогіка. Соціальна робота, 2012. Вип. 25. С. 148-151.

\section{References}

1. Pelling, N. The Short Prehistory of Gamification. Funding Star tups (\& Other Impossibilities). Journal of Nano Dome. Retrieved from https://nanodome. wordpress.com/2011/08/09/the-short-prehistory-of-gamification/ [in English]. 
2. Zichermann, G. (2011). Game mechanics in web and mobile apps. California: O'Reilly Media, 182 p. [in English].

3. Bartle, R. (2004). Designing virtual worlds. New Riders, 741 p. [in English].

4. Kim, A. (2010). Community building on the web: Secret strategies for successful online communitie. Addison-Wesley: Longman Publishing Co., 380 p. [in English].

5. Kap, K. (2012). The gamification of learning and instruction: game-based methods and strategies for training and education. San Francisco: Pfeiffer, 336 p. [in English].

6. Werbach, K. \& Hunter, D. (2012). Forthewin: how game thinking can revolutionize your business. Philadelphia: Wharton Digital Press, 148 p. [in English].

7. Huotari, K. \& Hamari, J. (2012). Defining gamification: a service marketing perspective. Journal of Proceedings of the 16th International Academic Mind Trek Conference, 17-22 [in English].

8. Clark, D. (2006). Games and e-learning. St. Peters Gate: Caspian Learning Ltd., 31 p. [in English].

9. Groh, F. (2012). Gamification: State of the Art Definition and Utilization. Journal of Paper presented at the 4th Seminar on Research Trends in Media Informatics, 39-46 [in English].

10. Mostova, A. D. (2018). Poniattia heimifikatsii ta yii rol u marketynhu. Journal of Yevropeiskyi vektor ekonomichnoho rozvytku, 1(24), 96-106. DOI: 10.32342/2074-5362-2018-24-9 [in Ukrainian].

11. Bezchotnikova, A. O. (2016). Zastosuvannia heimifikatsii dlia vyrishennia reklamnykh ta PR-zavdan. Journal of Visnyk Dnipropetrovskoho universytetu. Seriia 'Sotsialni komunikatsii', 16, 8-18 [in Ukrainian].

12. Sereda, H. V. (2017). Heimifikatsiia v menedzhmenti personalu: zarubizhnyi ta ukrainskyi dosvid. Journal of Ekonomika i orhanizatsiia upravlinnia, 4 (28), 216-223 [in Ukrainian].

13. Holovko, N. I. (2015). Ihrovi tekhnolohii yak zasib aktyvizatsii piznavalnoi diialnosti studentiv. Journal of Visnyk Kyivskoho natsionalnoho universytetu imeni Tarasa Shevchenka. Seriia Pedahohika, 1(1), 17-20 [in Ukrainian].

14. Serheieva, L. Heimifikatsiia: ihrovi mekhaniky motyvatsii personalu. Journal of Theory and methods of educational management. Retrieved from http://umo.edu.ua/images/content/nashi_vydanya/metod_upr_osvit/v_15/14. pdf [in Ukrainian].

15. Shcho take heimifikatsiiai chomu vona korysna. Retrieved from https://www.youtube.com/watch?v=vvVLYhVckR8 [in Ukrainian].

16. Nasyrova, S. (2019). Heimifikatsiia yak efektyvnyi instrument motyvatsii personalu suchasnoi orhanizatsii. Journal of Naukovyi ohliad, 3, 6-16 [in Ukrainian].

17. Ababilova, N. M. (2015). Osoblyvosti perekladu terminiv ukrainskoiu movoiu. Journal of Molodyi vchenyi, 2, 126-128 [in Ukrainian].

18. Gassler, G. \& Hug, T. \& Glahn, C. (2004). Integrated Micro Learning Anoutline of the basic method and first results. Journal of International Conference on Interactive Computer Aided Learning, 1-7 [in English].

19. Weber, Ch. (2003). Rapid learning in high velocity environment: dissertation to the degree of doctor of Philosophy In Management of Technological Innovation and Entrepreneurship. Massachusetts: Massachusetts Institute of Technology, 569 p. [in English].

20. Hug, T. (2006). Micro Learning and Narration Exploring possibilities of utilization of narrations and storytelling for the designing of 'microunits' and didactical micro-learning arrangements. Cambridge, 7-11 [in English]. 
21. Orosova, R. (2012). Zastosuvannia mikronavchannia u protsesi vyvchennia kursu 'zahalna dydaktyka' v Koshytskomu universyteti imeni Pavla Yozefa Shafaryka. Journal of Nauk. visn. Uzhhorod. nats. un-tu. Ser.: Pedahohika. Sotsialna robota, 25, 148-151 [in Ukrainian].

В статье структурированы этапы становления геймификации как социального и культурного явления, и как научного термина, предложены критерии однозначности средств геймификации, разработан метод анализа эффективности геймификованих материалов.

Ключевые слова: геймификация; геймификованый контент; мотивация; игры; тесты; пользователь.

The purpose of the work is to determine the social and communication essence of gamification and peculiarities of its functioning in various spheres of professional activity.

The object of the study is gamification as a socio-communication phenomenon, and the subject is to determine the feasibility and effectiveness of using gamification as a way to get the audience's attention to content in the educational process.

Keywords: gamification; gamified content; motivation; games; tests; user.

Рецензент - А. В. Литвин, канд. іст. наук, доц., КПІ ім. Ігоря Сікорського

Надійшла до редакції 25.09.19 